\title{
Assessment of Some Nigerian Coals for Metallurgical Application
}

\author{
I. O. Akpabio ${ }^{1}$, M. M. Chagga ${ }^{2}$ and A. Jauro ${ }^{1 *}$ \\ ${ }^{1}$ Chemistry Programme, Abubakar Tafawa Balewa University, P. M. B. 0248, Bauchi, \\ Bauchi State, Nigeria. \\ ${ }^{2}$ Scientific Services Department, National Metallurgical Development Centre (NMDC), \\ P.M. B 2116, Jos, Plateau State, Nigeria. \\ *Correspondence Author: E-mail: alijauro@daad-alumni.de.
}

\begin{abstract}
In the quest for a search of a suitable coal deposit of metallurgical importance, the qualities of three Nigerian coal samples, Lafia-Obi, Doho and Lamja, were assessed for possible utilization in metallurgical coke production. Several parameters that determine coking quality, such as moisture content, ash, volatile matter, free swelling index, sulphur content, Gray-King coke test, dilatation and plasticity (fluidity), were investigated. Lafia-Obi has the lowest moisture and volatile matter and the highest fixed carbon content. Its ash and sulphur contents are greater than that required by a coking but washing prior to use is expected to improve it. The volatile matter places Lafia-Obi in the medium-volatile bituminous rank, while Lamja and Doho are of medium-volatile bituminous rank. The rheological properties show that Lafia-Obi is the only caking coal. This put together single out Lafia-Obi as a potential candidate for coke making. Doho and Lamja coals may be useful for steam raising, liquefaction or chemicals manufacture.
\end{abstract}

Keywords: proximate analysis, coking coal, plastic properties, coke

\section{INTRODUCTION}

In order to curtail the importation of metallurgical spares and consumables, the Ajaokuta Steel Company Ltd was built to transform Nigeria Technologically. This dream is yet to be realized due to unavailability of prime coking coal locally. In spite of the reported occurrence of several coal deposits in the country, report on their coking potentials is still lacking [1]. Coal is a vital resource that can transform a country technologically and also substitute imported sources of 
energy supplies. If the indigenous coal deposits can be explored and exploited, Nigerian economy can be diversified, leading to a smooth industrial and technological transition from the present petroleum based economy [2]. Coking coal is a coal that softens, fuse and re-solidify when heated to form the carbon-rich material called coke. Metallurgical coke is one of the major raw materials needed in the production of iron by the blast furnace method. It acts as a reducing agent, reducing the iron ore to its elemental form.

This paper reports the results of proximate analysis and rheological properties of three Nigerian coals, Lafia-Obi (Nasarawa State), Doho (Gombe State) and Lamja (Adamawa State) and uses the results in assessing the coking potentials of the coals.

\section{MATERIALS AND METHODS}

\subsection{Materials}

The coal samples were collected directly from the coal fields at Lafia-Obi (Nasarawa state), Doho (Gombe state) and Lamja (Adamawa state). Samples collected were kept in an airtight polyethylene bags.

\subsection{Methods}

The coal samples were air dried, pulverized and sieved to pass $200 \mu \mathrm{m}$ sieve size [3]. The following parameters were determined.

(a) Inherent Moisture: $1 \mathrm{~g}$ of the powdered sample was placed in a pre-weighed silica crucible and subjected to a temperature of $105^{\circ} \mathrm{C}$ to $110{ }^{\circ} \mathrm{C}$ for 1 hour in the absence of air, until a constant weight was attained [3].

(b) Ash Content: $1 \mathrm{~g}$ of pulverized sample was weighed in to a platinum crucible and subjected to a temperature of $825{ }^{\circ} \mathrm{C}$ in a muffle furnace for about $4 \mathrm{hrs}$ until a constant weight was attained [3].

(c) Volatile Matter: $1 \mathrm{~g}$ of powdered coal sample was weighed and covered in a $10 \mathrm{ml}$ platinum crucible. The sample was subjected to a temperature of $925^{\circ} \mathrm{C}$ in a muffle furnace for 7 minutes [4].

(d) Gray-King Coke Test: 20g of powdered sample was weighed into a retort tube, pressed to a layer of about $15 \mathrm{~cm}$ long and then plugged with a cotton wool. A U-tube placed in a beaker filled with ice blocks was placed in a tubular furnace set between $325^{\circ} \mathrm{C} 600^{\circ} \mathrm{C}$ at a heating rate of $5{ }^{\circ} \mathrm{C} / \mathrm{min}$. The coke button obtained was compared with the standard shape profiles [5].

(e) Free Swelling Index: $1 \mathrm{~g}$ of the pulverized coal sample was weighed into a translucent crucible. It was covered and heated over a Bunsen burner for about 7 minutes. The button obtained was compared with the standard numbered profiles from 1-9 in $1 / 2$ Units [4]. 
(f) Total Sulphur (Eschka method): $1 \mathrm{~g}$ of pulverized sample was mixed with $3 \mathrm{~g}$ Eschka mixture. The mixture was heated to a temperature of $800{ }^{\circ} \mathrm{C}$ for 1 hour. The mixture was digested in water. The sulphur dissolved in water was precipitated as barium sulfate by the addition of barium chloride. The precipitate was filtered; reduced to ashes and the final weight determined gravimetrically [3].

(g) Plasticity (Fluidity): $5 \mathrm{~g}$ of powdered sample was weighed into a metal crucible equipped with a motorized stirrer. The sample was stirred as it was heated at a rate of $1^{\circ} \mathrm{C} /$ minute to a final temperature of $300^{\circ} \mathrm{C}$. Stirring force required as phase changes was recorded by the rate of stirrer's rotation [3].

(h) Dilatation: $5 \mathrm{~g}$ of the pulverized coal sample was pressed into a pencil and heated in a tubular finance with a piston weight on top. As the coal softened the sample contracts due to the piston weight. Also, as soften mass increased, the volatile components trapped in the pencil caused a dilatation (i.e. increase in volume of soften mass) [6].

\section{RESULTS AND DISCUSSION}

Table 1 shows the results of proximate analysis, Gray king assay, free swelling index, dilation and fluidity obtained from coal samples. Lafia-Obi has the lowest moisture content of $2.91 \%$, followed by Lamja with a value of $3.08 \%$. The highest moisture content of $3.90 \%$ was recorded in Doho sample. High moisture content would result in a decrease plant capacity and an increase in operating costs. This is by affecting the calorific value and the concentration of other constituents [7]. The moisture content required by a good coking coal is $1.5 \%$ [3]. Therefore values recorded in the coal samples are generally higher than that stipulated for a good coking coal.

Table 1: Proximate Analysis, Sulphur Content and Rheological Properties of Some Nigerian Coals.

\begin{tabular}{|c|c|c|c|c|}
\hline \multirow[b]{2}{*}{1.} & Parameters & \multicolumn{3}{|c|}{ Samples Identity } \\
\hline & Proximate Analysis & Lafia-obi & Doho & Lamja \\
\hline a. & Moisture (wt \%) & 2.91 & 3.90 & 3.08 \\
\hline b. & $\operatorname{Ash}(\% \mathrm{db})$ & 20.66 & 29.91 & 11.87 \\
\hline c. & Volatile matter (\% db) & 27.29 & 43.44 & 40.01 \\
\hline d. & Fixed carbon $(\%)$ & 46.23 & 21.98 & 44.23 \\
\hline e. & Total sulphur (\%) & 2.91 & 0.77 & 0.81 \\
\hline 2. & Gray king Assay & G3 & A & B \\
\hline 3. & Free Swelling Index & 6 & 0 & 0 \\
\hline 4. & Dilation \% & 23 & -5 & -5 \\
\hline 5. & Fluidity (ddpm) & 21 & 0 & 0 \\
\hline
\end{tabular}


The lowest ash content of $11.87 \%$ was observed in Lamja sample, followed by Lafia-Obi with a value of $20.66 \%$. Doho sample recorded the highest ash content of $29.91 \%$. Lower ash content is an essential requirement for coke making coals, because some of the ash would end up in the coke on carbonization, and in the blast furnace, the ash influences slag volume and composition. An ash content of less than $10 \%$ is recommended for a good coking coal [8]. Industrial experience indicates that a $1 \mathrm{wt}$. \% increase of ash in the coke reduces metal production by 2 or 3 wt. \% [9].

Lafia-Obi sample possess the lowest volatile matter of $27.29 \%$, followed by Lamja with a value of $40.01 \%$ and then Doho with the highest value of $43.44 \%$. The volatile matter content of medium volatile bituminous coal is around $22 \%$. This suggests that the Lafia-Obi coal is of medium volatile bituminous rank. Doho and Lamja coals may be of high volatile non-caking or weakly caking class of coals which are known to have volatile matter content of $36 \%$ and above. Volatile matter apart from its use in coal ranking is one of the most important parameters used in determining their suitable applications [10]. Volatile matter does not form part of the coal; it is usually evolved as tar during carbonization.

The fixed carbon content of the coal samples shown on Table 1 revealed that Lafia-Obi sample has the highest carbon content of $46.23 \%$ followed by Lamja with a value of $44.23 \%$. The least carbon content of $21.98 \%$ is found in Doho sample. The fixed carbon content of the coal is the carbon found in the material after volatile materials are driven off. It is used as an estimate of the amount of coke that will be yielded from a sample of coal [11]. This suggests that Lafia-Obi sample with the highest value has more carbon for coke formation, followed by Lamja and then Doho.

Doho coal has the lowest sulphur content of $0.77 \%$, followed by Lamja with a value of $0.81 \%$. The highest sulphur content of $2.91 \%$ is observed in Lafia-Obi sample. In the carbonization process sulphur is undesirable because most of it would be retained in the coke. This sulphur has to be removed from iron and steel-making by either modifying the blast-furnace burden with a consequence reduction in iron output or by external desulphurizing technique which are both money and time-consuming. An acceptable level for sulphur in coking coal blends for furnace coke production should not exceed 1.5-1.60\% [12]. Therefore the sulphur contents of both Doho and Lamja are within the required range of a good coking coal while that of Lafia-Obi is beyond. Coals are purified by washing prior to carbonization. Therefore a decrease in sulphur and ash contents to the coking coal requirement is expected of Lafia-Obi, when purified. Walker, et al., reported a significant reduction in sulphur and ash yield between washed and unwashed coals [13].

The Gray-king test and free swelling index (FSI) shown on Table 1, gave a comparative G3 profile for Lafia-Obi coal, indicating that the coal has a good coking potential. A good 
metallurgical coal usually possesses a Gray-king profile between G1 to G9. Doho and Lamja coals have Gray-king type A and B profiles respectively which suggest that they are of poor coking qualities. This observation is supported by the Free Swelling Index which gave zero values for both Doho and Lamja, shows that they are non-agglomerating and hence non-caking. The FSI depends on both rank and coal type. If a single coal is to be used for coke manufacture, an intermediate value (4-6) for this parameter is probably desirable [11, 14]. Therefore, Free Swelling Index of six (6) recorded for Lafia-obi sample show that it has a good agglomerating character that is expected of a good coking coal. The dilatation and fluidity for Lafia-Obi sample are 23\% and 21 dial division per minute (ddpm) which is good for a coking coal. Zero values recorded for both Doho and Lamja, also support their non-caking behavior.

\section{CONCLUSION}

The studies conducted revealed that Lafia-Obi coal has the lowest moisture, volatile matter and highest fixed carbon content, followed by the Lamja and then Doho. The volatile matter content, places Lafia-Obi in the medium-volatile bituminous rank, while Lamja and Doho are classed as high-volatile bituminous. Even though the ash and sulphur content of Lafia-Obi is higher than that of Lamja, Doho and that required by a coking coal, purification prior to use is expected to improve its quality. Gray-king assay and free swelling index show that only Lafia-Obi is caking. The results combined together, single out Lafia-Obi as the only potential candidate for metallurgical coke making.

\section{REFERENCES}

[1] Okolo, H. C., and Mkpadi, M. C., 1996, Coal in the energy mix of Nigeria, In: Nigerian Coal, a Resource for Energy and Investments, pp.12-16, (Okolo, H. C. and Mkpadi, M. C., Eds.), Mufadenic Press, Lagos.

[2] Famuboni, A.D., 1996, Maximizing exploration of Nigeria's coal reserves, In: Nigerian Coal, a Resource for Energy and Investments, pp. 39-61, (Okolo, H. C. and Mkpadi, M. C., Eds.), Mufadenic Press, Lagos.

[3] American Society for Testing and Materials, 1992, Annual Book of ASTM Standards, Section 5.05, Petroleum Products, Lubricants and Fossil Fuels.

[4] Montgomery, W. F., 1978, Standard laboratory test methods for coal and coke, In: Analytical Methods for Coal and Coal Products, Volume 1, pp. 194-224, (Karr, C., Ed.), Academic Press, New York.

[5] British Standard Institute, 1991, Assessment of coking power by Gray-king coke test, In: Methods for Analysis and Testing of Coal and Coke, pp. 4-12, London.

[6] Bellview, N., 1995, Report on the Laboratory and Pilot Scale Assessment of Coal, Report submitted to NNDC Jos, pp.1-7, Mabinuori Dawodu Press. 
[7] International Energy Agency (IEA)/Organization for Energy Co-operation and Development (OECD), 2002, Coal in the Energy Supply of India, p. 28, Paris.

[8] Bustin, R. M., Cameron, A. R., Greve, D. A., and Kalkreuth, W. D., 1985, Coal Petrology: Its Principles, Methods and Applications, Geological Association of Canada., Course Notes Volume 3, p. 230.

[9] Price, J., Gransden, J., and Hampel, K., 1997, Microscopy, Chemistry and Rheology, Tools to Determining Coal and Coke Characteristics, $1^{\text {st }}$ McMaster's cokemaking course. 4.1-4.74, McMaster's University Hamilton, Ontario, Canada.

[10] Peng C., 2002, "Petrographic Characteristics of Chinese Coals and their Applications in Coal Utilization Processes.” J. Fuel, Vol. 81, pp. 11-12.

[11] Diez, M. A., Alvarez, R. and Barriocanal, C., 2002, Coal for Metallurgical Coke Production: Prediction of Coke Quality and Future Requirements for Coke Making." Int. J. Coal Geology, Vol. 50, pp. 289-412.

[12] Williams, K., 1977, "Primary Coal-Analytical Needs." J. Pure and Applied Chemistry, Vol. 49, pp. 1465-1473, Pergamon, Great Britain.

[13] Walker, R., Mastalerz, M. and Padgett, P., 2001, "Quality of Selected Coal Seams from Indiana: Implications for Carbonization.” Int. J. of Coal Geology, Vol. 47, pp. 277-288.

[14] Ward, C. R., 2002, Coal Geology, In: Encyclopedia of Physical Science and Technology, Volume 3, pp. 45-76, Academic Press, London. 
